The suggestion put forward by Mr. MeEvoy, the Town Clerk, in stating the case for the application, was that excavation should proceed under skilled archæological supervision, the cost entailed over and above the normal cost of excavation to be borne by a local committee representing those interested in ancient remains. Against this, Mr. Colin D. R. Elles, the chairman of the excavation committee, handed in a petition, which had been signed by 3,235 persons in four days only, asking that the remains should be preserved; while Mr. Baillie Reynolds not only stated that his department would look with great favour on any scheme to preserve the remains, but also intimated that the Office of Works would co-operate in laying them out to advantage.

\section{Forensic Medicine}

THE Advisory Committee on the Scientific Investigation of Crime, under the chairmanship of Lord Trenchard, recently issued its report (London: H.M. Stationery Office, 1936. 2d. net), from which it would appear that the teaching of forensic medicine in London is in an extremely backward condition as com. pared with the teaching of that subject in most of the capitals of Europe, and well behind the standard set in Scotland. As the Committee points out, this is not confined to the restricted sphere of criminal investigation and police practice, but extends to the study of many problems connected with social medicine and to the whole question of medico-legal practice. The Committee recommends the establishment of a medico-legal institute which would act as a training centre for medico-legal experts and as a centre for special pathological research, and it also suggests that facilities should be given for courses of instruction for students of law, coroners and other persons who are associated with medico-legal work.

As to the question of police laboratories, though in certain circumstances it is no doubt advisable to have laboratory facilities under the direction of the police, the proper place for extensive medico-legal investigations is in connexion with departments of universities. If the investigating authorities are to have the facility of obtaining advice on all kinds of scientific subjects, as they must, there is no possibility of so doing if they are restricted to police laboratories. Such advice and assistance can be obtained only through the universities. It is, however, impossible for the police authorities to know what departments to consult, and therefore a department of forensic medicine within the university offers the only means by which full use of the latest advances in science may be obtained. On considering the whole matter, it would appear to be advisable for the authorities in London to concentrate their efforts in founding a Department of Forensic Medicine in connexion with the University of London, and to make the necessary arrangements for the ample material, which is at present largely wasted, to be utilized in the teaching of elementary forensic medicine to medical students and to offer facilities for postgraduate study and research to those who desire to specialize in this subject.

\section{Technical College Equipment}

WE have received from an Advisory Committee on Technical College Equipment, British Industries House, Marble Arch, London, W.1, a memorandum on a scheme in progress for setting up an exhibition at British Industries House showing the equipment necessary for technical institutions. This movement is designed to help those responsible for expenditure on these centres in view of the very large outlay anticipated during the next few years by the Board of Education. The Committee represents the three associations concerned with technical teaching and also the Institution of Production Engineers, and hence is an authoritative body. It is pointed out that the present method of deciding on a design, that of visiting recent buildings and utilizing the composite information obtained, wastes time and is unsatisfactory. Technical education in Great Britain is lamentably behind that on the Continent in the matter of material equipment and buildings, hence this scheme is to be commended. The relationships of the pieces of mechanism will no doubt be an important part of the Committee's work, though this must be to some extent subservient to the configuration of the floor space. More difficult will be the presentation of the structural features and service supplies essential as the basis of the equipment. It is stated that the object is to enable full information to be obtained for getting out estimates for building, extending, and equipping institutions. So far as the two former functions are concerned, it seems difficult to see how the exhibition can supply any detailed information, from the province of trained professional advisers and necessarily varying with local conditions; such advisers, however, should be able to learn much from the exhibition.

\section{Geological Survey and Museum: New Activities}

A NEw publications stall, where the public may purchase the official guides and geological memoirs, including the series of handbooks on British Regional Geology referred to in NatuRE of September 5 (p. 389), has been opened in the entrance hall of the new Geological Museum at South Kensington. The Museum has also published an extensive series of excellent photographic postcards, price $1 d$. each, which are likely to be of value to teachers of geology and physical geography. The postcards include reproductions of general views of the Museum, with dioramas and other interesting exhibits; and photographs of British localities of geological interest, with explanatory text, illustrating marine erosion and sea coasts, rock-weathering and denudation, vulcanism, glaciation, and similar subjects. A list is obtainable from the Museum. An experimental series of free public lantern lectures and lecture tours on the geology and scenery of various regions of Great Britain was given last month. The lectures were well attended, and will be continued throughout the winter. Facilities for special parties can be arranged. Recent additions to the exhibited collections include a series of specimens from H.M. Office of Works, illustrating the weathering of the building stone 
(Anston stone) of the Houses of Parliament; and a suite of ores illustrating the occurrence of copper at Kilembe, presented by the Geological Survey of Uganda. This occurrence, which is in granulitic rocks, is remarkable for the presence of the cobalt ore linnæite, although arsenic and antimony are absent. Among the donations recently received by the petrographical department there is a valuable series of rock-specimens from the Pre-Cambrian of the Adirondacks, New York State, collected and presented by Dr. A. F. Buddington of Princeton University; and a second fine collection from the Charnwood Forest and Nuneaton areas, presented by Mr. H. H. Gregory of the Leicester Museum.

\section{Empire Fauna at Home and Abroad}

THE August number of the Journal of the Society for the Preservation of the Fauna of the Empire presents some interesting contrasts in its varied accounts of wild life in different British territories. Capt. C. R. S. Pitman, to whose reports as Game Warden of the Uganda Protectorate NATURE has referred on previous occasions, in a lecture to the Society, explained why organized control of the 21,000 elephants of the Protectorate became necessary. The devastation caused by such great numbers in a limited area (of some 80,000 square miles), where the native population averages forty to the square mile, became intolerable, and yet under organized control, and in spite of the fact that 17,000 elephants have been slain in twelve years, the estimated number remains as it was in 1924. Capt. Pitman is of opinion that organized control is the finest insurance for the adequate perpetuation of the African elephant. From wild Africa we turn to the home of animal protection-and read Miss Frances Pitt's article upon the polecat and pine-marten in Great Britain. The elephants are over-numerous, do serious harm, are deliberately slaughtered, and syet their continued existence is secured; the polecat and pine-marten are rare, are two of the most interesting members of the primitive fauna which survive in Britain, they do no particular harm in any serious degree, and yet-the first is extinct in Scotland and England, and survives only on the Welsh border, and the latter is apparently extinct, or all but extinct, throughout the whole country except in the north-west of Scotland; and almost all because these creatures are liable to find their way into traps set for vermin. It is ironical that while we concern ourselves with the fauna of the Empire abroad, these two creatures should be disappearing in our own land under our eyes. Can no step be taken to ensure their adequate perpetuation, as the adequate perpetuation of destructive elephants in Uganda is ensured ?

\section{Marine Biology at Cullercoats}

THE Report for the year ending July 31, 1935, of Armstrong College Dove Marine Laboratory, Cullercoats, Northumberland, drawn up by the director, Prof. A. D. Hobson, and published by the Marine Laboratory Committee of Armstrong College, shows a successful period in the history of the Laboratory. Further alterations in the building have given more working space and the library has been extended, with most satisfactory results. Herring observations have been continued in accordance with those of previous years, also salmon investigations, the results of the latter work having been published in the Annual Report of the Tyne Salmon Conservancy Board. Interesting results have been obtained by Dr. Bull in his experiments on conditioned responses in fishes in connexion with changes of salinity, and he has also continued his observations on pollution in the Tyne estuary. Faunistic work, which has been made a speciality of the Laboratory researches, is progressing rapidly, many new additions have been made to the fauna, and a reference collection is in process of formation which will be of great value to future workers. A mussel survey of the Northumberland beds has been completed, and a report prepared and submitted to the Northumberland Sea Fisheries Committee. This report appears in the present publication, showing that the Holy Island and Budle Bay beds are the only areas of importance for bait supplies. Papers on the herring investigations by B. Storrow and Dorothy Cowan, on conditioned responses in fishes (Part 6) by $H$. O. Bull, and on heterogonic growth in the abdomen of Carcinus monas by J. H. Day (see NaTuRE, April 18, 1936, p. 669) are also included.

\section{Weed Problems in Australia}

As in some other parts of the world, noxious weeds are proving a serious source of trouble in Australia. The problem has been under the consideration of the Standing Committee of Agriculture and independently by several of the bodies represented on it. An arrangement was made in 1934 that as a preliminary to further work an officer of the Council for Scientific and Industrial Research should undertake a survey of the problem, the economic importance of different weeds, methods of control which had been already tried and their results, and so forth; his report to include recommendations for further co-operative work. The survey was undertaken by Mr. G. A. Currie, of the Division of Economic Entomology, assisted in certain aspects by Mr. J. Calvert, of the Division of Plant Industry. The report has been recently drawn up by $\mathrm{Mr}$. Currie, and the more important portions of it are published by the Council for Scientific and Industrial Research of Australia in Pamphlet No. 60, "A Report on a Survey of Weed Problems in Australia" (Melbourne: Government Printer, 1936). Apart from the study made of past records of the activities and damage resulting from weeds, the weed legislation of each State was studied and the methods of administration ascertained. The pamphlet outlines the losses incurred from weeds, and the existing methods of control and the relation of dangerous weed growth to various primary industries. There is much in this pamphlet which could be studied with advantage in Great Britain. Among the sixteen weeds selected as being the most important in Australia are such well-known ones as bracken, stinkwort, thistles, blackberry, St. John's wort, lantana, ragwort, convolvulus and wild turnip.

(Continued on p. 459.) 